\section{HETEROSIS AND INBREEDING DEPRESSION IN INDIAN MUSTARD [BRASSICA JUNCEA (L.) CZERN \& COSS]}

KEY WORDS: Indian mustard, Brassica juncea, Relative heterosis, Heterobeltiosis, Inbreeding depression.

\section{Abhinaya*}

\section{H L Dhaduk}

\section{P Manivel}

\section{N. Kapadia}

Bansilal Amrutlal college of Agriculture, Anand agricultural University, Anand-3881 10, Gujarat. *Corresponding Author

Bansilal Amrutlal college of Agriculture, Anand agricultural University, Anand-3881 10, Gujarat.

Bansilal Amrutlal college of Agriculture, Anand agricultural University, Anand-3881 10, Gujarat.

Bansilal Amrutlal college of Agriculture, Anand agricultural University, Anand-3881 10, Gujarat.

The present investigation was undertaken with a view to generate information on heterosis and inbreeding depression for seed yield and its component traits in six hybrids of Indian mustard (Brassica juncea (L) Czern \& Coss). Out of the six hybrids, hybrid GM-3 $\times$ EC766495 showed maximum relative heterosis while the cross GM-2 $\times$ EC766434 exhibited the highest heterobeltiosis It also showed significant and positive estimates for both $\mathrm{RH}$ and $\mathrm{HB}$ for siliqua length, number of siliqua per plant, yield per plant and oil content. Yield attributing characters like seeds per siliqua, siliqua length and number of siliqua are positive and significant for the crosses GM-1 $\times$ EC766043, GM-2 × EC766434, GM-3 $\times$ EC766495, GDM-4 $\times$ EC766590. Among all the crosses, the cross GDM-4 $\times$ EC766590 had significant estimates of inbreeding depression in desired direction for seeds per siliqua and siliqua length indicating the possibility for desired transgressive segregants for the characters under consideration.

\section{INTRODUCTION}

Among the oilseed crops, mustard (Brassica juncea (L.) Czern \& Coss) is a widely adapted crop of Asiatic origin with its major center of diversity in China. Indian mustard (Brassica juncea (L.) is the predominantly grown species in India, accounting for about $80 \%$ of cultivated area (Ram et al., 2012). The exploitation of hybrid vigour will depend upon the direction and magnitude of heterosis, biological feasibility and nature of gene action involved. Yield is an important economic character and is an outcome of multiplicative interaction of component characters. In general, parents are selected on the basis of their per se performance, but many times high yielding genotype may/may not transmit its superiority to progeny. Hence, critical choice of parents is of utmost importance, particularly for the improvement of complex quantitative characters such as yield.

The magnitude of heterosis provides a basis for genetic diversity and a guide for the choice of desirable parents for developing superior $F_{1}$ hybrids to exploit hybrid vigour and/or building gene pool to be employed in breeding programs. Study of heterosis has been recognized as an important approach for genetical improvement of yield and its attributing characters in mustard. Promising $F_{1}$ can directly be included in evaluation trials, while others exhibiting heterosis for one or the other desirable trait may be advanced further to obtain transgressive segregants.

\section{MATERIAL AND METHODS}

The experimental material comprised of ten genotypes i.e. GM-1, GM-2, GM-3, GDM-4, EC766043, EC766434, EC766495, EC766590, RH-119 and RH-406 which were selected on the basis of their geographic origin and wide variation in morphological characters. The experiment involved the six basic generations (the $P_{1}$ and $P_{2}$ parent cultivars, the $F_{1}$ and $F_{2}$ first and second filial generations, and the $B_{1}$ and $B_{2}$ first and second back crosses) of six combinations of the parental cultivars (GM-1 × EC766043, GM-2 × EC766434, GM-3 × EC766495, GDM-4 $\times$ EC766590, GM-1 $\times$ RH-1 19 and GM-2 $\times$ $\mathrm{RH}-406)$. Populations were cultivated in a compact block family design with three replications during the rabi season of 2017-2018 at the Agronomy farm of Anand Agricultural University in Anand, Gujarat, India.

The individual replication was represented by six families and each family block was of one row for each of $P_{1}, P_{2}$ and $F_{1}$, two rows of $B_{1}$ and $B_{2}$ and four rows of $F_{2}$ generation. Fifteen plants were accommodated in each row with $45 \times 15 \mathrm{~cm}$ inter and intra row spacing. The characters studied were days to $50 \%$ flowering, days to maturity, plant height (cm), number of primary branches per plant, number of secondary branches per plant, length of main branch, number of seeds per silique, silique length (cm), number of siliqua per plant, 1000 seed weight (g), yield per plant ( $g$ ), oil content (\%), protein content (\%) and aphid scoring. The heterotic effects in term of superiority of $F_{1}$ over better parent (heterobeltiosis) as per Fonseca and Patterson (1968); over mid parent value (relative heterosis) as per Turner (1953); and inbreeding depression was worked out as loss in vigour due to inbreeding and difference between mean of $F_{1}$ and $F_{2}$.

\section{RESULTS AND DISCUSSION}

The perusal of results of observed and expected relative heterosis, heterobeltiosis and inbreeding depression are presented in Table 1. For the seed yield, all the crosses showed positive and significant relative heterosis.

For days to $50 \%$ flowering, the estimates of relative heterosis in six crosses ranged from -7.54 per cent $(\mathrm{GM}-1 \times \mathrm{EC} 766043)$ to 6.02 per cent (GM-1 $\times$ RH-119). The crosses GM-1 $\times$ EC766043 (-7.54) and GM-3 × EC766495 (-5.14) exhibited significant and negative relative heterosis ( $\mathrm{RH}$ ) which is desirable for earliness. In heterobeltiosis (HB), the cross GM$1 \times$ EC766043 (-4.22) depicted significant and negative heterosis over better parent. These results are in agreement with the results of Khulbe et al. (1998), Kumbhalkar et al. (2000), Parmar et al. (2004), Mahto and Haider (2008), Macwana (2008), Gupta et al. (2011), Nasrin et al. (2011), Saeed et al. (2013), Kumar et al. (2013) and Niranjana (2014).

The estimates of heterosis over mid parental value was highest with the cross GM-2 $\times$ RH-406 (-5.21) for days to maturity. Whereas the cross GM-1 $\times$ RH-1 19 (-13.55) depicted significant and negative heterobeltiosis for plant height. These results were similar to the findings of Khulbe et al. (1998) and Kumbhalkar et al. (2000). The crosses GM-2 $\times$ RH$406(53.14 \%)$, GM-1 $\times$ EC766043 (45.12\%) and GM-1 $\times$ RH$119(6.24 \%)$ depicted significant and positive relative heterosis, and for heterobeltiosis, the estimates were significant and positive with the same three crosses GM- $1 \times$ 
EC766043 (43.20\%) followed by GM-2 $\times$ RH-406 (38.89\%) and GM-1 $\times$ RH-1 $19(0.64 \%)$ for number of primary branches per plant. These findings were similar to Khulbe et al. (1998), Kumbhalkar et al. (2000), Mahto and Haider (2004), Nasrin et al. (2011), Saeed et al. (2013) and Niranjana (2014).

The cross GM-1 × EC766043 (23.67\%) exhibited significant relative heterosis in positive direction for length of main branch, these results are in conformity with the reports of of Pal and Ghosh (1992), Khulbe et al. (1998) and Kumar and
Rathore (2004). For number of seeds per siliqua, the cross GM$1 \times$ RH-119 (22.26\%) exhibited highest relative heterosis followed by GM-3 $\times$ EC766495 (12.78\%) and GDM-4 $\times$ EC766590 (12.49\%). The character siliqua length found hightest relative heterosis in GM-2 × EC766434 (10.41\%). The highest heterosis for the number of siliqua was found with the cross GM-3 × EC766495 (17.74\%). The results of number of seeds per siliqua, siliqua length are in conformity with findings of Kumbhalkar et al. (2000) and Acharya and Swain (2003).

Table 4.3.1: Relative Heterosis (RH \%), heterobeltiosis (BP \%) and inbreeding depression for various characters in six crosses in Indian mustard.

\begin{tabular}{|c|c|c|c|c|c|c|c|c|c|c|c|c|c|c|c|c|c|c|}
\hline \multirow[t]{2}{*}{ ters } & \multicolumn{3}{|c|}{$\begin{array}{c}\text { GIM-1 } \times \\
\text { EC766043 }\end{array}$} & \multicolumn{3}{|c|}{$\begin{array}{c}\text { GIM-2 } \times \\
\text { EC766434 }\end{array}$} & \multicolumn{3}{|c|}{$\begin{array}{c}\text { GIM-3 } \times \\
\text { EC766495 }\end{array}$} & \multicolumn{3}{|c|}{$\begin{array}{l}\text { GDIM-4 } \times \\
\text { EC766590 }\end{array}$} & \multicolumn{3}{|c|}{ GM-1 × RH-119 } & \multicolumn{3}{|c|}{ GM-2 $\times$ RH-406 } \\
\hline & & HB & & & HB & ID & & 2 & ID & & -7 & ID & & & & & & \\
\hline to & 1.18) & $\mid \begin{array}{c}* * \\
(0.97)\end{array}$ & $(0.9$ & $\begin{array}{l}60 \\
98)\end{array}$ & ) & $\begin{array}{c}-7.96 \\
* * \\
(0.66)\end{array}$ & $\begin{array}{c}-5.14 \\
* * \\
(1.10)\end{array}$ & & $\begin{array}{c}-2.32 \\
* \\
(0.91)\end{array}$ & $\begin{array}{l}2.16 * \\
(0.12)\end{array}$ & $\left(\begin{array}{c}7.17 * \\
* \\
(0.82)\end{array}\right.$ & $\begin{array}{c}-4.54 \\
* * \\
(0.58)\end{array}$ & $(6$ & $\begin{array}{l}12 \\
0\end{array}$ & & & $\begin{array}{c}.10 * \\
* \\
.75)\end{array}$ & 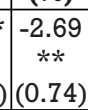 \\
\hline & $\begin{array}{c}* \\
(1.16\end{array}$ & & & & $\begin{array}{c}2.21^{*} \\
* \\
(0.84)\end{array}$ & $\begin{array}{c}-3.31 \\
* * \\
(0.86)\end{array}$ & & & & & & $\begin{array}{c}0.50 \\
(0.94)\end{array}$ & & & & 8) & & \\
\hline & $\begin{array}{c}* \\
1.2 \\
\end{array}$ & $\left\{\begin{array}{c}7 \\
* \\
(1.20)\end{array}\right.$ & & * & & \begin{tabular}{|l|}
-2.55 \\
$(1.43)$
\end{tabular} & $\begin{array}{c}(10.5 \\
6)\end{array}$ & & \begin{tabular}{|c|}
-0.76 \\
$(10.3$ \\
$9)$ \\
\end{tabular} & & & $\begin{array}{l}.39 \\
.85)\end{array}$ & & ( & & & & \\
\hline & $\begin{array}{c}* \\
(0.4\end{array}$ & $\begin{array}{c}43.20 \\
* * \\
0.41)\end{array}$ & $\begin{array}{r}-4.1 \\
* * \\
0.3\end{array}$ & & & $\begin{array}{c}-28.6 \\
1 * * \\
(0.33)\end{array}$ & $\begin{array}{c}-6.41 \\
* *\end{array}$ & & $\mid \begin{array}{c}1.81^{*} \\
* \\
(0.25)\end{array}$ & & & \begin{tabular}{|c|}
-52.5 \\
$5 * *$ \\
$(0.18)$
\end{tabular} & 6. & & & & 9 & * \\
\hline & $\begin{array}{c}2.78 \\
* \\
(0.86\end{array}$ & (c) & $\begin{array}{c}-0.50 \\
(0 . \\
64) \\
\end{array}$ & & & $\begin{array}{c}-54.3 \\
3 * * \\
(0.73)\end{array}$ & $\begin{array}{c}-18.2 \\
7 * * \\
(1.15)\end{array}$ & & & & & $\begin{array}{c}-33.5 \\
3 * * \\
(0.87)\end{array}$ & & & & & 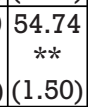 & 4 \\
\hline 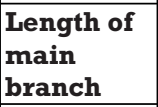 & $\begin{array}{c}23.67 \\
* * \\
(1.18) \\
\end{array}$ & $\begin{array}{l}16 \\
(1\end{array}$ & $\begin{array}{c}55.59 \\
* * \\
(1.55)\end{array}$ & $\begin{array}{c}-2.89 \\
* \\
(1.35)\end{array}$ & $-\begin{array}{c}-2.97 \\
*\end{array}$ & $\begin{array}{c}-0.69 \\
(1.23)\end{array}$ & & & $\begin{array}{c}-6.07 \\
* * \\
(1.43)\end{array}$ & $\begin{array}{c}-13.0 \\
0 * * \\
(1.27)\end{array}$ & $\begin{array}{c}-16.4 \\
9 * * \\
(1.23)\end{array}$ & $\begin{array}{c}-12.4 \\
5 * * \\
(1.23)\end{array}$ & & & & 4 & * & * \\
\hline & $.88^{*}$ & & $\begin{array}{c}7.08 * \\
* \\
(0.22)\end{array}$ & & & $\begin{array}{c}-24.1 \\
1 * * \\
(0.75) \\
\end{array}$ & & *) & $\begin{array}{c}2.39 * \\
* \\
(0.36)\end{array}$ & $\begin{array}{c}12.49 \\
* *\end{array}$ & $\begin{array}{c}11.36 \\
* * \\
(0.51)\end{array}$ & $\begin{array}{c}-6.00 \\
* * \\
(0.38)\end{array}$ & & 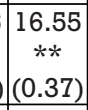 & $\left\{\begin{array}{c}9.88 * \\
* \\
(0.35)\end{array}\right.$ & \% & * 0 & to \\
\hline & $\begin{array}{r}3.2 \\
\text { * } \\
(0.1\end{array}$ & $\begin{array}{c}0.54 * \\
*\end{array}$ & $\begin{array}{c}5.13^{*} \\
* \\
(0.10)\end{array}$ & 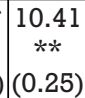 & $\begin{array}{l}.73^{*} \\
*\end{array}$ & $\begin{array}{c}7.38 * \\
* \\
(0.26)\end{array}$ & $\begin{array}{r}8.6 \\
*\end{array}$ & $\begin{array}{c}6.01 * \\
*\end{array}$ & $\begin{array}{c}4.34 * \\
*\end{array}$ & $\begin{array}{c}4.63^{*} \\
*\end{array}$ & $\mid \begin{array}{c}-0.21 \\
* *\end{array}$ & $\mid \begin{array}{c}-11.1 \\
6 * * \\
(0.09)\end{array}$ & & ( & $\begin{array}{c}-5.59 \\
* *\end{array}$ & & $\begin{array}{l}.9 \\
*\end{array}$ & 1 \\
\hline & & $\begin{array}{r}-2.8 \\
(16 . \\
0) \\
\end{array}$ & $\begin{array}{r}(14 . \\
0)\end{array}$ & . & $\begin{array}{c}12.72 \\
* * \\
(2.57) \\
\end{array}$ & $\mid \begin{array}{c}0.33 \\
(2.52)\end{array}$ & 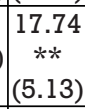 & $\begin{array}{l}1.61 \\
*\end{array}$ & $(5.02$ & 0 & & $\begin{array}{c}-27.4 \\
9(49 \\
.51) \\
\end{array}$ & & 1 & \begin{tabular}{|c}
-0.61 \\
$(60.7$ \\
$8)$ \\
\end{tabular} & & $\begin{array}{c}(36.7 \\
9)\end{array}$ & (9) \\
\hline & $5.78 *$ & & $\begin{array}{c}-2.99 \\
* *\end{array}$ & & $\begin{array}{l}13.3 \\
0 * * \\
.11)\end{array}$ & $\begin{array}{r}-6.5 \\
* * \\
(0.1\end{array}$ & & & $\begin{array}{r}-7 . \\
* \\
0 .\end{array}$ & 9.33* & $\begin{array}{c}-7.05 \\
* * \\
(0.12)\end{array}$ & -1.72 & & (C & -1.53 & & $\begin{array}{c}-10.8 \\
5 * *\end{array}$ & $\begin{array}{c}4.23 \\
*\end{array}$ \\
\hline & $70 *$ & $\begin{array}{l}3.8 \\
3 * * \\
.50) \\
\end{array}$ & $47 *$ & & $\begin{array}{c}22.40 \\
* * \\
(0.86)\end{array}$ & $\begin{array}{c}3.53 * \\
* \\
(0.94)\end{array}$ & $\begin{array}{c}27.39 \\
* *\end{array}$ & $\begin{array}{c}18.65 \\
* * \\
(1.70)\end{array}$ & $\begin{array}{c}15.11 \\
* * \\
(1.19)\end{array}$ & $\begin{array}{c}19.30 \\
* * \\
(0.89)\end{array}$ & & $\begin{array}{l}2.63 * \\
(1.06)\end{array}$ & 79 & 57 & $\begin{array}{c}9.77^{*} \\
* \\
(1.25)\end{array}$ & 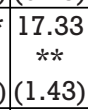 & $\begin{array}{l}6.48 \\
* *\end{array}$ & 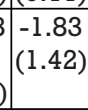 \\
\hline & 2 & $\begin{array}{c}-1.08 \\
*\end{array}$ & ( & $7 *$ & $\mid \begin{array}{c}4.46 * \\
*\end{array}$ & $\begin{array}{c}-2.78 \\
* * \\
(0.41)\end{array}$ & $8.75 *$ & $\begin{array}{c}5.70 * \\
*\end{array}$ & -1 & $\begin{array}{c}9.55 * \\
*\end{array}$ & 6 & $\begin{array}{c}-3.69 \\
* * \\
(0.32)\end{array}$ & & & $\begin{array}{c}-13.7 \\
6 * * \\
0.51)\end{array}$ & 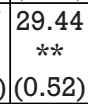 & $\begin{array}{l}9.50 \\
* *\end{array}$ & M \\
\hline & 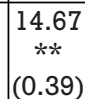 & $\begin{array}{c}-7.78 \\
* * \\
(0.30)\end{array}$ & -1. & $\begin{array}{c}-9.01 \\
* * \\
(0.44)\end{array}$ & $\begin{array}{c}-10.3 \\
4 * * \\
(0.35)\end{array}$ & $5.77^{*}$ & $6.19 *$ & $2.90 *$ & $\begin{array}{c}10.56 \\
* *\end{array}$ & $\begin{array}{c}6.10 * \\
* \\
0.37)\end{array}$ & * $\begin{array}{c}3.18^{*} \\
*\end{array}$ & $\mid \begin{array}{c}11.22 \\
* * \\
0.25)\end{array}$ & $4.35 *$ & $\begin{array}{c}3.76 * \\
*\end{array}$ & 0.07 & $\begin{array}{c}5.20 * \\
*\end{array}$ & $\begin{array}{c}2.49 * \\
*\end{array}$ & $\begin{array}{c}9.52 \\
*\end{array}$ \\
\hline & -9.20 & -18.9 & $\begin{array}{c}-15.4 \\
2 * *\end{array}$ & $\begin{array}{c}-18.6 \\
7 * *\end{array}$ & -25.5 & $\begin{array}{c}-23.1 \\
8 * *\end{array}$ & $\begin{array}{c}-36.7 \\
6 * *\end{array}$ & -41.3 & $\begin{array}{c}-39.3 \\
8 * *\end{array}$ & -9.20 & $\begin{array}{c}-16.8 \\
5 * *\end{array}$ & $\begin{array}{c}22.91 \\
* *\end{array}$ & $3.59 *$ & $\begin{array}{c}2.21 * \\
*\end{array}$ & $\begin{array}{c}-17.7 \\
5 * *\end{array}$ & $\begin{array}{c}-13.2 \\
1 * *\end{array}$ & $\begin{array}{c}-23.3 \\
4 * *\end{array}$ & $\begin{array}{c}-19 \\
5 *\end{array}$ \\
\hline
\end{tabular}

\section{N.B: () - figures in parentheses represent SEm values}

For seed yield per plant, all the crosses showed positive and significant relative heterosis with the minimum and maximum values of relative heterosis ranging from $6.70 \%(\mathrm{GM}-1 \times$ EC766043) to $27.39 \%($ GM-3 $\times$ EC766495) respectively. Whereas, for heterobeltiosis, the cross GM-2 $\times$ EC766434 $(22.40 \%)$ exhibited the highest heterobeltiosis. These results are Nasrin et al. (2011) and Meena et al. (2013). For oil content, the values of heterosis over mid parent ranged from $-10.24 \%$ $(\mathrm{GM}-1 \times \mathrm{RH}-119)$ to $29.44 \%$ (GM-2 $\times \mathrm{RH}-406)$. In respect to heterobeltiosis, the cross GM-2 $\times$ RH-406 (19.50\%) showed the highest value. These findings are in agreement with the reports of Khulbe et al. (1998), Kumbhalkar et al. (2000),
Parmar et al. (2004) and Macwana (2008) as they reported low estimates of heterosis.

For the character protein content, it was significant and positive for all the crosses except GM-2 $\times$ EC766434 which exhibited significant and negative heterosis. In respect to heterobeltiosis, four crosses namely GM-3 × EC766495 (2.90\%), GDM-4 × EC766590 (3.18\%), GM-1 × RH-119 (3.76\%) and GM-2 $\times$ RH-406 (2.49\%) showed significant and positive heterotic effect. For aphid scoring, the cross GM-1 $\times$ RH-119 as it depicted significant and positive heterosis $(3.59 \%)$ and heterobeltiosis $(2.21 \%)$. These results are in 
agreement with the results of Singh (2003) and Niranjana (2014).

The estimate of inbreeding depression was significant and negative in crosses Laxmi x IC 399797 (-2.30\%) and GM 1 x Vardan $(-3.32 \%)$ for days to maturity which earlier reported by Khulbe et al. (1998) and Hrive and Tiwari (1991). In respect to inbreeding depression, except for the cross GM-1 $\times$ EC766043 all the other crosses showed negative estimates of inbreeding depression which are similar to the earlier finding of Mishra (2010). The crosses GM-3 × EC766495 (1.81\%) and GM-2 $\times$ RH-406 (1.40\%) exhibited significant and positive inbreeding depression for primary branches per plant, whereas for secondary branches per plant the crosses GM-2 $\times$ EC766434 (-54.33\%), GM-3 × EC766495 (-43.21\%), GDM-4 $\times \operatorname{EC766590}(-33.53 \%)$ and GM-1 $\times$ RH-119 (-20.00\%) expressed significant negative and the cross GM-2 $\times$ RH-406 $(19.26 \%)$ expressed significant positive inbreeding depression which are akin with the result of Thakur and Bhateria (1993). For the length of main branch, the crosses GM-3 × EC766495 (-6.07\%) and GDM-4 × EC766590 ($12.45 \%$ ) exerted significant and negative inbreeding depression. The estimate of inbreeding depression was significant and positive for crosses GM-1 × EC766043 (7.08\%), GM-3 × EC766495 (2.39\%), GM-1 × RH-1 19 (9.88\%) and GM-2 $\times$ RH-406 (15.03\%)) for number of seeds per siliqua. Inbreeding depression was significant and negative for the crosses GDM-4 × EC766590 (-11.16\%), GM-1 × RH-119 $(-5.59 \%)$ and GM-2 $\times$ RH-406 (-5.41\%) for siliqua length. None of the crosses exhibited significant and negative inbreeding depression for number of siliqua per plant.

For 1000 seed weight, the cross GM-1 $\times$ RH-119 (-1.53\%) depicted least inbreeding depression followed by GDM- 4 EC766590 (-1.72\%) and GM-1 × EC766043 (-2.99\%). All the crosses (table 4.3.1), except the cross GM-2 $\times$ RH-406, exhibited significant and positive inbreeding depression for seed yield per plant which is undesirable. These findings are similar to the results of Thakur and Bhateria (1993) and Mishra (2010). Inbreeding depression estimates were significant and negative effect for oil content with the crosses GM-2 $\times$ EC766434 (-2.78\%), GM-3 × EC766495 (-18.79\%), GDM-4 $\times$ EC766590 (-3.96\%) and GM-1 $\times$ RH-1 19 (-13.76\%). For the character, protein content, only one cross GM-1 × EC766043 ($1.18 \%$ ) exhibited significant and negative estimates. In respect to aphid scoring, the crosses GM-1 $\times$ EC766043 ($15.42 \%)$, GM-2 $\times$ EC766434 (-23.18\%), GM-3 $\times$ EC766495 ($39.38 \%)$, GM-1 $\times$ RH-1 19 (-17.75\%) and GM-2 $\times$ RH-406 ($19.55 \%)$, exhibited significant and negative estimates of inbreeding depression.

\section{REFERENCES}

1. Acharya N. N. and Swain D. 2003. Combining ability of seed yield and its components in Indian mustard [Brassica juncea (L.) Czern \& Coss]. Indian J. Agric.Res., 38(1):40-44.

2. Fonseca S. and Pattenson F. 1968. Hybrid vigour in a seven parent diallel cross in common winter wheat (Triticum aestivum L.). Crop Sci., 8:85-88.

3. Gupta P. and Kumar L. S. 2011. Heterosis and combining ability analysis for yield and its components in Indian mustard [Brassica juncea (L.) Czern \& Coss].Acad.J.Plt. Sci., 4(2):45-52.

4. Hirve C. D. and Tiwari A. S. 1991. Heterosis and inbreeding depression in Indian mustard. Indian J. Genet., 51 (2): 190-193.

5. Khulbe R. K., Pant D. P. and Rawat R. S. 1998. Heterosis for yield and its components in Indian mustard.J. Oilseeds Res., 15(2):219-226.

6. Kumar D. and Rathore N. 2004. Comparative studies on combining ability and heterosis for yield and yield components in Indian mustard, [Brassica juncea (L.) Czern \& Coss] on normal and saline soils.J. Oilseeds Res., 21 (1):24-27.

7. Kumar P., Alankar L., Yadav R. K., Singh L. and Singh M. 2013. Analysis of yield and its components based on heterosis and combining ability in Indian mustard (Brassica juncea (L.) Czern and Coss). The Bioscan, 8 (4): 1497-1502.

8. Kumbhalkar H. B., Dawande V. B., Niar B. and Patil S. 2000. Heterosis breeding in Indian mustard.J. Oilseeds Res., 17(2):354-355.

9. Macwana S. S. 2008. Genetic analysis of seed yield and its attributes in Indian mustard (Brassica juncea L.) over environments. Unpublished Ph. D. Thesis submitted to Anand Agricultural University, Anand.

10. Mahto J.L. and Haider Z. A. 2004. Heterosis in Indian mustard (Brassica juncea (L.) Czern \& Coss). J.Tropic. Agric., 42 (1-2):39-41.

11. Meena H. P., Kumar H. and Lal, J. P. 2013. Heterosis and combining ability in Indian mustard [Brassica juncea (L.) Czern \& Coss].J. Oilseeds Res., 30 (1):5559 .

12. Mishra, P. (2010). Generation mean analysis for seed yield and its components in Indian mustard [Brassica juncea (L.) Czern \& Coss] over environments. M. Sc. (Agri.) Thesis submitted to Dept. of Plant Breeding, A. A. U., Anand.

13. Nasrin S., Nur F., Nasreen K., Bhuiyan S. R., Sarkar S. and Islam M. M. 2011. Heterosis and combining ability analysis in Indian mustard (Brassica juncea (L.)). Bangladesh Res.Pub.J., 6 (1):65-71.

14. Niranjana M. 2014. Diallel analysis for yield and contributing character in Indian mustard [Brassica juncea (L.) Czern \& Coss]. M.Sc. (Agri.). Thesis submitted to Anand Agricultural University, Anand.

15. Parmar A. N., Patel K. M. and Thakkar D. A. 2004. Heterosis for yield and its components in Indian mustard. [Brassica juncea (L.) Czern \& Coss].J. Oilseeds Res., 21(2):325-326.

16. Ram S. and Verma N.2012. Genetic variability for yield and yield components in Indian mustard [Brassica juncea (L.) Czern \& Coss]. J. Oilseed Brassica, 27 (2): 170-171.

17. Saeed F., Muhammad H.N.T., Shehzad A. K., Muhammad R. J., Jehanzeb F. and Saeed M. 2013. Heterosis and combining ability for seed yield and its components in Indian mustard (Brassica juncea). Albanian J. Agric. Sci., 12 (2): 203-208.

18. Thakur H. K. and Bhateria S. C. 1993. Heterosis and inbreeding depression in Indian mustard [Brassica juncea (L.) Czern \& Coss]. Indian J. Agric. Sci., 43: 1055-1059.

19. Turner J.H. 1953. A study of heterosis in upland cotton, combining ability and inbreeding effects. Agron.J., 45:487-490. 